\title{
Agnieszka Motyl \\ Normalizacja fleksji werbalnej w zakresie kategorii czasu $w$ dobie średniopolskiej \\ Wydawnictwo Poznańskiego Towarzystwa Przyjaciół Nauk, Poznań 2014, ss. 325
}

Rozprawa Agnieszki Motyl sytuuje się w obszarze historii języka polskiego (w szerokim jej rozumieniu, włączającym do niej ewolucję systemu językowego polszczyzny, stanowiącą $\mathrm{w}$ tradycyjnym ujęciu przedmiot gramatyki historycznej). Sama autorka bardzo precyzyjnie - co warte podkreślenia, gdyż bynajmniej nie powszechne - charakteryzuje cel swojej pracy:

„Celem pracy jest ukazanie procesów normalizacyjnych form czasownikowych w zakresie czasu teraźniejszego i przyszłego prostego, przyszłego złożonego i czasów przeszłych w dobie średniopolskiej i ich szczegółowa analiza. Przeprowadzone badania mają ukazać, jakie tendencje dominowały $\mathrm{w}$ średniopolskiej koniugacji, $\mathrm{w}$ jakim tempie zachodziły zmiany i jakie czynniki na to wpływały. Pozwoli to na wyodrębnienie momentów przełomowych $\mathrm{w}$ rozwoju czasownika $\mathrm{w}$ badanym okresie i zestawienie ich z cezurami wyznaczanymi w periodyzacjach polskiego języka literackiego" (s. 16).

Na podstawie dotychczasowej literatury przedmiotu autorka, moim zdaniem absolutnie zasadnie, wybrała do opisu, analizy i interpretacji trzynaście procesów szczegółowych, „[...] najlepiej charakteryzujących fleksję werbalną w dobie średniopolskiej" (s. 33). Są to: 1) rywalizacja końcówek 1. os. lm. - $m$ i -my, 2) rywalizacja - w tejże kategorii - końcówek -imy (-ymy) i -emy, 3) rywalizacja form prezentywnych typu dawa, stawa i typu daje, staje, 4) przesunięcia koniugacyjne typu bieży - biegnie, ciecze - cieknie, dosięże - dosięgnie, kradzie - kradnie, roście - rośnie, rzecze - 
rzeknie itp., 5) wyrównania w tematach czasownikowych w rodzaju bierze zamiast biore, grzebię zamiast grzebę, skubię zamiast skubę, sypię zamiast sypę, zowię zamiast zowę, żywię i później żyję zamiast żywę itp., 6) ekspansja nowych form czasu teraźniejszego czasownika być: jestem, jesteś, jesteśmy, jesteście, 7) ekspansja i zanik form jestech, jestechmy i sachmy, 8) ewolucja w zakresie szyku elementów składowych czasu przeszłego, 9) regres końcówki preterytalnej -chmy (bylichmy, robilichmy), 10) zanik czasu zaprzeszłego, 11) ewolucja łączliwości enklityki werbalnej w czasie zaprzeszłym, 12) ewolucja w zakresie szyku członów czasu zaprzeszłego i 13) ewolucja w zakresie budowy form czasu przyszłego złożonego.

Równie precyzyjnie jak cel swojej rozprawy scharakteryzowała autorka jej podstawy teoretyczne (koncepcję normy, normalizacji, wariantu i wariantywności, języka literackiego i jego regionalnych wariantów) oraz przyjętą w pracy metodologię. Generalnie sytuuje się ona w obrębie paradygmatu strukturalistycznego, a składają się na nią: metoda przekrojów synchronicznych Ireny Bajerowej, perspektywa paraleli autorstwa Kwiryny Handke i instrumentarium badawcze językoznawstwa statystycznego (spod znaku Władysława Kuraszkiewicza, Jadwigi Sambor, Ireny Bajerowej, Wojciecha Ryszarda Rzepki i innych historyków języka polskiego). W sumie jest to metodologia spójna i adekwatna zarówno do celów rozprawy, jak i do zgromadzonego przez autorkę obfitego i różnorodnego materiału językowego.

W tym miejscu należy również podkreślić indywidualny wkład Agnieszki Motyl do precyzyjnie scharakteryzowanego (na s. 23-31) instrumentarium badawczego zastosowanego w rozprawie. Polega ten wkład przede wszystkim na twórczym zaadaptowaniu metody przekrojów synchronicznych. Z zasady pomyślana ogólnie, o charakterze ramowym, metoda ta wymaga - w każdym wypadku jej zastosowania - modyfikacji uwzględniających realia chronologii i podstawy źródłowo-materiałowej prowadzonych badań. Autorka - jak najbardziej zasadnie - wyróżniła w obrębie doby średniopolskiej pięć okresów ze szczegółowo wyznaczonymi przekrojami synchronicznymi (obejmującymi od dziesięciu do szesnastu lat). „W każdym z [...] przekrojów przebadany został materiał o objętości całkowitej od 120000 do 220000 wyrazów" (s. 27). Łącznie daje to imponującą liczbę 920000 wyrazów w 58 tekstach-źródłach (w tym sześciu dodatkowych), wyekscerpowanych w całości, jeśli liczba wyrazów oscylowała wokół 20 000, bądź w wypadku tekstów dłuższych, w postaci próby losowej takiej wielkości, wyłącznie drukach (co autorka 
przekonująco uzasadnia: „Ze względu na to, iż celem pracy jest prześledzenie procesu normalizacji, badaniami obejmuję język druków. Druki lepiej bowiem niż rękopisy ilustrują społecznie uznawaną normę, na którą w tym czasie duży wpływ mieli drukarze, zecerzy i korektorzy. Wykluczone zostały rękopisy jako mniej znormalizowane, bardziej nacechowane regionalnie i indywidualnie. Nie bez znaczenia jest również fakt, iż obieg społeczny rękopisów, a zatem i ich oddziaływanie na normę ogólną, był mniejszy niż obieg druków" (s. 28)), dobranych z różnych regionów proporcjonalnie do ich udziału $\mathrm{w}$ produkcji wydawniczej i z uwzględnieniem zróżnicowania tematycznego dzieł (proza narracyjna, postylle i kazania, proza religijno-polemiczna i moralizatorska, literatura polityczna świecka, literatura specjalna, proza urzędowa). Nie może ulegać wątpliwości, że tak skonstruowaną podstawę źródłowo-materiałową rozprawy należy uznać za wzorową.

Przyjmując taką podstawę i uzbrojona w wyżej zwięźle scharakteryzowane spójne i adekwatne do celów pracy i zgromadzonego materiału językowego instrumentarium badawcze, osiągnęła autorka zamierzony cel badawczy. Powstała praca obszerna (325 stron), wyjątkowo sumienna, gruntowna, przekonująca i wiarygodna w warstwie wyników naukowych i w zamierzonym zakresie wyczerpująca. O jej wartości stanowią - moim zdaniem - przede wszystkim następujące aspekty i elementy:

1) Wybór tematu. Autorka wzięła na warsztat wciąż jeszcze - mimo istniejących opracowań - niedostatecznie rozpoznany wycinek ewolucji systemu fleksyjnego języka doby średniopolskiej. Można więc zasadnie stwierdzić, że jej rozprawa wypełnia odczuwalną lukę w naukowej literaturze historycznojęzykowej.

2) Wzorowo skonstruowana podstawa źródłowo-materiałowa pracy i równie wzorowe założenia teoretyczne i instrumentarium badawcze (o czym już była mowa wyżej).

3) Samoistna wartość informacyjna Wstępu i Części I (tu za szczególnie cenne uważam spójne, głęboko przemyślane refleksje na temat normy i normalizacji oraz - a może w szczególności - wariantów i wariantywności).

4) Budzące uznanie zaplecze erudycyjne rozprawy. Wykaz bibliograficzny, w którym nie dostrzegam żadnych braków i pominięć, poza źródłami obejmuje (przypomnijmy, że praca dotyczy niedostatecznie rozpoznanego wycinka ewolucji polskiej koniugacji $\mathrm{w}$ dobie średniopolskiej) 160 opracowań, w tym 55 książek, nierzadko wielotomowych. Na- 
leży przy tym podkreślić, że gruntowna i krytyczna znajomość literatury przedmiotu ma w rozprawie Agnieszki Motyl charakter w wysokim stopniu "sfunkcjonalizowany": jej wyniki, umiejętnie przez autorkę wyzyskane, konstytuują tło i wieloraki kontekst naukowy jej pracy, która dzięki temu zyskuje na głębi i gruntowności.

5) Szczegółowość, wielostronność, precyzja, a nierzadko wręcz finezja opisu, analizy i interpretacji. W obszernej Części II, zatytułowanej Analiza materiału (s. 33-297), autorka gruntownie, wszechstronnie i drobiazgowo opisała trzynaście wybranych (wyliczonych już na wstępie niniejszej recenzji) procesów szczegółowych, charakteryzujących fleksję werbalną w dobie średniopolskiej. Autorka, co jest rozwiązaniem zasadnym metodologicznie, merytorycznie i kompozycyjnie, a bardzo wygodnym dla czytelnika pracy, przyjęła stały schemat opisu, analizy i interpretacji tych procesów. Schemat obejmuje: informację (krytyczną, skomentowaną) o stanie badań, informację o zasobie materiału zgromadzonego przez doktorantkę, opis ogólny procesu (z wyzyskaniem przejrzystych tabel, operujących liczbami bezwzględnymi i relacjami procentowymi), opis z uwzględnieniem regionalnych wariantów polszczyzny (małopolskiej, wielkopolskiej, mazowieckiej, północno- i południowokresowej), opis według uzusu drukarń i wreszcie opis relacjonujący stan w poszczególnych źródłach. Już ta charakterystyka daje wyobrażenie o bogactwie zaprezentowanych w pracy szczegółowych danych językowych, które mogą być wyzyskiwane w najrozmaitszych kontekstach badawczych.

6) Zalety eksplikacyjno-kompozycyjne rozprawy, tzn. zalety wykładu i walory układu (przejrzystego i logicznego) pracy. W szczególności chciałbym tu podkreślić znaczenie dwu kwestii: wartości informacyjnej licznych i przejrzystych tabel i wykresów oraz trafnego i gruntownie przemyślnego rozkładu informacji między tekst główny i poboczny (przypisy): w przypisach, często bardzo "gęstych" informacyjnie (absolutnie nie do pobieżnego oglądu, nie mówiąc już pominięciu), autorka pomieściła informacje ważne i interesujące, nieraz zgoła fundamentalne, jednak z perspektywy głównego wywodu - przynajmniej w tym miejscu drugorzędne; zabieg ten bardzo korzystnie wpływa na płynność zasadniczej narracji naukowej.

7) I wreszcie, jako skutek wszystkich wyliczonych wyżej walorów, interesujące i ważne wyniki naukowe. Dotyczące regionalnych wariantów polszczyzny autorka zebrała w paragrafie Zróżnicowanie regionalne procesów normalizacyjnych (s. 295-297), a ich całość - w Zakończeniu (s. 299-309). 
Pogrupowała tam szczegółowe procesy normalizacyjne w cztery zespoły, zbliżone pod względem chronologii, tempa i wyników składających się na nie procesów (co autorka ilustruje przejrzystymi wykresami). Nie ma tu miejsca, by szczegółowo relacjonować jej ważne ustalenia, ograniczę się więc do najogólniejszego i fundamentalnego w perspektywie historii języka polskiego wniosku o zasadności przyjmowanej przez niektórych badaczy (Tadeusza Lehra-Spławińskiego, Stanisława Słońskiego, Stanisława Urbańczyka) cezury (jako wewnętrznej cezury w obrębie doby średniopolskiej) w połowie XVII wieku.

8) Na koniec trzeba podkreślić formalne walory rozprawy: nieskazitelną pisownię (łącznie $\mathrm{z}$ interpunkcją, co jest już dzisiaj ewenementem zasługującym na szczególne uwypuklenie), sprawną i poprawną polszczyznę w odmianie naukowej (którą autorka, świetna stylistka, włada ze swadą, szczęśliwie łącząc precyzję z jednej, a swobodę z drugiej strony), wreszcie wyjątkowo staranną redakcję rozprawy (co już jest też zasługą Wydawnictwa PTPN).

W świetle powyższego wywodu nie ulega wątpliwości, że bardzo wartościowa praca Agnieszki Motyl wpisuje się na listę podstawowych lektur historyka języka polskiego.

Bogdan Walczak

Uniwersytet im. Adama Mickiewicza

Państwowa Wyższa Szkoła Zawodowa im. Jakuba z Paradyża w Gorzowie Wielkopolskim 